\title{
Breast density in women with premature ovarian failure or postmenopausal women using hormone therapy: analytical cross-sectional study
}

\author{
Densidade mamária em mulheres com falência ovariana prematura ou na pós-menopausa e \\ em uso de terapia hormonal: estudo transversal analítico
}

\author{
Patrícia Magda Soares', César Cabello", Luis Alberto Magna"', Eduardo Tinois ${ }^{\text {IV }}$ Cristina Laguna Benetti-Pinto ${ }^{\text {IV }}$
}

KEY WORDS:

Hormone replacement therapy. Mammography.

Menopause.

Premature ovarian failure. Breast.

PALAVRAS CHAVE:

Terapia de reposição hormonal Mamografia.

Menopausa.

Falência ovariana prematura. Mama.

\begin{abstract}
CONTEXT AND OBJECTIVE: Studies on postmenopausal women have reported increased risk of breast cancer relating to the type and duration of hormone therapy (HT) used. Women with premature ovarian failure (POF) represent a challenge, since they require prolonged $\mathrm{HT}$. Little is known about the impact of prolonged HT use on these women's breasts. This study aimed to evaluate the effects of one type of HT on the breast density of women with POF, compared with postmenopausal women.

DESIGN AND SETTING: Cross-sectional study at the Department of Obstetrics and Gynecology, Universidade Estadual de Campinas (Unicamp). METHODS: 31 women with POF and 31 postmenopausal women, all using HT consisting of conjugated equine estrogen combined with medroxyprogesterone acetate, and matched according to $\mathrm{HT}$ duration, were studied. Mammography was performed on all subjects and was analyzed by means of digitization or Wolfe's classification, stratified into two categories: non-dense (N1 and P1 patterns) and dense (P2 and Dy). RESULTS: No significant difference in breast density was found between the two groups through digitization or Wolfe's classification. From digitization, the mean breast density was $24.1 \% \pm 14.6$ and $18.1 \% \pm 17.2$ in the POF and postmenopausal groups, respectively $(P=0.15)$. Wolfe's classification identified dense breasts in $51.6 \%$ and $29.0 \%$, respectively $(P=0.171)$.

CONCLUSION: There was no difference in breast density between the women with POF and postmenopausal women, who had used HT for the same length of time. These results may help towards compliance with HT use among women with POF.
\end{abstract}

\section{RESUMO}

CONTEXTO E OBJETIVO: Estudos com mulheres na pós-menopausa relatam aumento no risco de câncer de mama relacionado ao tipo e duração da terapia hormonal (TH) utilizada. Mulheres com falência ovariana prematura (FOP) representam desafio por necessitarem de TH prolongada. Pouco se conhece sobre ação da TH nas mamas dessas mulheres. Este estudo objetivou avaliar os efeitos de um tipo de TH sobre a densidade mamária de mulheres com FOP comparativamente à de mulheres pós-menopausa.

TIPO DE ESTUDO E LOCAL: Estudo de corte transversal no Departamento de Tocoginecologia, Universidade Estadual de Campinas (Unicamp). MÉODOS: Estudaram-se 31 mulheres com FOP e 31 mulheres na pós-menopausa, todas usando TH com estrogênio conjugado equino mais acetato de medroxiprogesterona, pareadas pelo tempo de utilização da TH. Todas realizaram mamografia, analisada por digitalização e por classificação de Wolfe, estratificada em duas categorias: não densa (padrão N1 e P1) e densa (P2 e Dy).

RESULTADOS: Não houve diferença significativa entre a densidade mamária dos grupos analisadas por digitalização ou classificação de Wolfe. Pela digitalização, calculou-se densidade mamária média em $24.1 \% \pm 14.6$ e $18.1 \% \pm 17.2$ nas com FOP e pós-menopausa, respectivamente $(P=$ 0,15); pela classificação de Wolfe identificou-se mamas densas em $51,6 \%$ e 29,0\%, respectivamente ( $P=0,171)$.

CONCLUSÃ0: Não se observou diferença na densidade mamária de mulheres com FOP comparativamente à de mulheres na pós-menopausa utilizando TH pelo mesmo período de tempo. Estes resultados podem auxiliar na aderência à TH de pacientes com FOP.

\section{INTRODUCTION}

Studies carried out on postmenopausal women have shown increased risk of breast cancer relating to the type of hormone therapy (HT) used and the duration of its use. ${ }^{1-7}$ It is still a matter for debate whether HT causes a reduction in the sensitivity and specificity of mam- mographic screening as a result of the increase in breast density..$^{8-10}$ The absolute risk of developing breast cancer, for a postmenopausal woman using estrogen-progestin HT, is individually very low (an increase of eight cases per 10,000 women annually). However, the cumulative effect has greater repercussions and is not considered insignificant in the case of prolonged use. ${ }^{11}$

'MD, Postgraduate student, Department of Obstetrics and Gynecology, School of Medical Sciences, Universidade Estadual de São Paulo (Unicamp), Campinas, São Paulo, Brazil.

"MD, PhD. Associate professor, Department of Obstetrics and Gynecology, School of Medical Sciences, Universidade Estadual de Campinas (Unicamp), Campinas, São Paulo, Brazil.

"'MD, PhD. Titular professor, Department of Medical Genetics, School of Medical Sciences, Universidade Estadual de Campinas (Unicamp), Campinas, São Paulo, Brazil.

"Thysicist and engineer, Biomedical Engineering Center, Universidade Estadual de Campinas (Unicamp), Campinas, São Paulo, Brazil.

${ }^{\mathrm{V} M D}$, PhD. Professor, Department of Obstetrics and Gynecology, School of Medical Sciences, Universidade Estadual de Campinas (Unicamp), Campinas, São Paulo, Brazil. 
Women with premature ovarian failure (POF) represent a challenge, since they require prolonged hormone therapy in view of their early loss of gonad function. However, little is known about the impact of prolonged HT use on these women's breasts. ${ }^{11}$ Concern about breast cancer is one of the most frequent causes of discontinuation of HT. ${ }^{12}$

Recently, postmenopausal changes in breast density, as evaluated by mammography, have been considered to be a strong marker for the risk of breast cancer. Breast density has been shown to reveal information on the exposure to endogenous and exogenous hormones that affect the environment in which cancer originates and develops. ${ }^{10}$ Various studies have shown that women with denser breasts have a two to six-fold higher risk of developing cancer, compared with women with less dense breasts. ${ }^{13-17}$

Much information linking HT and breast density in postmenopausal women has been published in the literature. ${ }^{7,18-23}$ However, to the best of our knowledge, no papers evaluating the breast density of women with POF have been published, even though these women are frequently treated with HT in the same way as postmenopausal women.

\section{OBJECTIVE}

Considering the scientific evidence, the questions regarding the effect of estrogen-progestin hormone therapy on postmenopausal breast density and the lack of information on women with premature ovarian failure regarding this subject, a study was carried out to compare breast densities between women with POF who were using estrogen-progestin HT and postmenopausal women using the same type of HT for similar lengths of time.

\section{MATERIAL AND METHODS}

This cross-sectional pilot study evaluated 31 women between 30 and 40 years of age with a diagnosis of POF shown by secondary amenorrhea with hypergonadotropic hypoestrogenism, with follicle-stimulating hormone $(\mathrm{FSH})>40 \mathrm{mIU} / \mathrm{ml}$ at two different times. ${ }^{24}$ These women were receiving care at the gynecological endocrinology outpatient clinic of the Department of Obstetrics and Gynecology, Universidade Estadual de Campinas (Unicamp), and they had been using an estrogen-progestin HT regimen composed of $0.625 \mathrm{mg}$ of conjugated equine estrogen (CEE) combined with medroxyprogesterone acetate (MPA), cyclically or continuously, for at least 12 months. Women who had some form of pathological condition and/or had undergone previous breast surgery, women who smoked more than 20 cigarettes/ day and those with body mass index $(\mathrm{BMI})>30 \mathrm{~kg} / \mathrm{m}^{2}$ were excluded from the study.

This group was compared with a control group of 31 postmenopausal women who were using the same hormone therapy as a cyclic or continuous regimen. The control group women were matched with the women in the study group according to duration of hormone use $( \pm 11$ months). They were selected from the menopause clinic of the Department of Obstetrics and Gynecology, Unicamp. Women over 50 years of age for whom the menopause had been diagnosed at least 12 months previously were eligible for inclusion in the study. The exclusion criteria were identical to those of the study group.

All the women in both groups underwent mammography, and the data were analyzed and compared using both the technique of mammographic digitization ${ }^{25}$ and Wolfe's classification. ${ }^{26}$ However, the patients were stratified into only two groups: non-dense breasts (N1 and P1 patterns) and dense breasts (P2 and Dy patterns).

The study protocol was approved by the Institutional Review Board of the Department of Obstetrics and Gynecology, Unicamp, and by the Ethics Committee of the School of Medicine, Unicamp.

Mammography was carried out using a high-resolution scanner (CGR Senographe 500T, GE Medical Systems) with a Kodak RPXOMAT processor. Kodak diagnostic films were used, and the left midlateral oblique incidence was used for digitization.

The mammogram films were placed on a negatoscope-type apparatus and covered by a sheet of transparent tracing paper. The outlines of the images corresponding to the fibroglandular and fatty portions were sketched by a specialist in mammography. Areas with the same density as the pectoralis major muscle were considered to be fibroglandular, while the remainder was considered to be fatty tissue. The drawings were digitized using a Hewlett Packard scanner and an IBM 486 desktop computer (DX4, 8 RAM, 540 HD). Digitization fragmented the figure into small areas referred to as pixels (picture elements). In the computer, the images were opened using an image editing software program (Paintbrush, Microsoft), in which the fatty areas were colored light grey and the fibroglandular areas were colored black. A numerical value of 250 was attributed to the light grey areas and zero to the black areas. The images were evaluated using the Mathlab4 software program by a specialist in physics, to quantify the percentage of glandular tissue in relation to the total volume of the breast, thus resulting in the dependent variable of breast density.

Evaluation of breast density was also carried out in accordance with Wolfe's classification. However, it was subdivided into only two categories: non-dense (N1 and $\mathrm{P} 1$ patterns, i.e. fibroglandular tissue accounting for $<25 \%$ of the breast volume in the left mid-lateral oblique incidence) and dense (P2 and Dy patterns, i.e. fibroglandular tissue accounting for $\geq$ $25 \%$ of the breast in the left mid-lateral oblique incidence). The specialist in mammography and the physicist who performed the analyses were blinded with regard to the identities of the groups.

Means and standard deviations were calculated to analyze the variables of age, parity and BMI. For the comparison of breast density between groups (digitization technique), Student's t-test for independent groups was used after performing the Kolmogorov-Smirnov test for normality. For analysis on Wolfe's classification, stratified into two categories, proportions were compared using the chi-square test in contingency tables. ${ }^{27}$ The significance level was established at 5\%. The software used for the statistical analyses was the Statistical Package for the Social Sciences (SPSS), version 15.0 for Windows 2006.

\section{RESULTS}

The mean age of the women with POF was $36.9 \pm 2.9$ years and the mean age of the postmenopausal women was $58.4 \pm 5.1$ years (variable 
approximately normally distributed in both groups: $\mathrm{P}=0.388$ and $\mathrm{P}=$ 0.652 respectively). The two groups were paired according to the duration of hormone therapy use ( \pm 11 months). Hormone therapy (CEE + MPA) had been used for a mean of $50.3 \pm 39.0$ months by women in the POF group and for a mean of $50.1 \pm 38.4$ months by the women in the postmenopausal control group (variable also approximately normally distributed in both groups: $\mathrm{P}=0.386$ and $\mathrm{P}=0.403$ respectively). There was no statistically significant difference in duration of HT use between the two groups $(\mathrm{P}=0.98)$. The mean time since diagnosis of POF was $85.9 \pm 44.4$ months, whereas the mean time since diagnosis of menopause was $117.7 \pm 57.6$ months (this variable also being approximately normally distributed in both groups: $\mathrm{P}=0.870$ and $\mathrm{P}=0.680$ respectively).

With regard to the other variables evaluated, the women with POF had had fewer pregnancies than had the postmenopausal women $(1.5 \pm$ 1.7 and $3.7 \pm 2.6$ pregnancies, respectively, $\mathrm{P}<0.001$; variable approximately normally distributed in both groups: $\mathrm{P}=0.290$ and $\mathrm{P}=0.192$ respectively). Fewer of the women with POF had breastfed than had the women in the control group $(54.8 \%$ of the women with POF and $81.7 \%$ of the control group, $\mathrm{P}=0.005)$.

Although women with BMI $>30 \mathrm{~kg} / \mathrm{m}^{2}$ had been excluded from enrollment in the study, the difference in BMI between the group with POF $(24.1 \pm 3.2)$ and the control group $(25.8 \pm 3.3)$ was statistically significant $(\mathrm{P}=0.04)$. BMI was approximately normally distributed in both groups $(\mathrm{P}=0.809$ and $\mathrm{P}=0.480$ respectively).

The percentage of breast density analyzed using mammographic digitization, a variable that was approximately normally distributed in both groups ( $\mathrm{P}=0.976$ and $\mathrm{P}=0.268$ respectively), was $24.1 \pm 14.6 \%$ in the POF group and $18.1 \pm 17.2 \%$ in the control group. This difference was not statistically significant $(P=0.15)$. Wolfe's classification, stratified into two subgroups (non-dense: fibroglandular tissue occupying an area $<25 \%$ of the breast; and dense: fibroglandular tissue occupying an area $\geq 25 \%$ of the breast), also failed to detect any statistically significant difference in breast density between the two groups, although $51.6 \%$ of the women with POF had dense breasts, compared with only $29 \%$ of the postmenopausal group $(\mathrm{P}=0.171)$ (Table $\mathbf{1})$.

\section{DISCUSSION}

No difference in breast density was found between the women with POF and the postmenopausal women using hormone therapy with conjugated equine estrogens and medroxyprogesterone acetate for similar periods of time, either when analyzed objectively using digitization or subjectively in accordance with Wolfe's classification. However, in both groups, the percentage of fibroglandular tissue in relation to the total area of the breast was low $(24.1 \pm 14.6 \%$ and 18.1 $\pm 17.2 \%$, respectively).

In the POF group, which was composed of younger women (mean age $36.9 \pm 2.9$ years), the mean time elapsed since gonad failure was shorter than in the control group. Other factors that could have protectively contributed towards the reduction in breast density were in fact less frequent in the POF group, in which the women had had fewer
Table 1. Breast density of women with premature ovarian failure (POF) and postmenopausal women ( $n=31$ in each group) analyzed according to digitization and Wolfe's classification

\begin{tabular}{|c|c|c|c|c|c|}
\hline \multirow{4}{*}{$\%$ Breast density } & \multicolumn{5}{|c|}{ Breast density according to mammographic digitization } \\
\hline & \multicolumn{2}{|c|}{ POF } & \multicolumn{3}{|c|}{ Postmenopausal (controls) } \\
\hline & Mean & SD & Mean & SD & P-value \\
\hline & 24.1 & 14.6 & 18.1 & 17.2 & $0.15^{*}$ \\
\hline & \multicolumn{5}{|c|}{ Breast density according to Wolfe's classification } \\
\hline$\%$ non-dense & \multicolumn{2}{|c|}{48.4} & \multicolumn{2}{|c|}{71.0} & $0.171^{\dagger}$ \\
\hline$\%$ dense & \multicolumn{2}{|c|}{51.6} & \multicolumn{2}{|c|}{29.0} & $0.171^{\dagger}$ \\
\hline
\end{tabular}

P-value < 0.05; 'Student's t test; ${ }^{\dagger}$ Chi-square test $\left(\chi^{2}\right) . S D=$ standard deviation.

pregnancies and fewer women had breastfed. Despite these characteristics, breast density in the study group was no different from that of the control group.

This study does not enable conclusions to be reached regarding the causes of this finding, but one hypothesis may be that the hypoestrogenism following gonad failure, which would cause regression of fibroglandular tissue and its progressive replacement by fatty tissue, ${ }^{18,20}$ may have greater repercussions in reducing breast density when present at a younger age.

One concern regarding increased breast density resulting from estrogen-progestin replacement therapy relates to impaired mammographic sensitivity and specificity. This would result in a higher number of falsepositive results, since the dense glandular tissue tends to make identification of tumorous masses more difficult, ${ }^{9,10}$ thereby compromising the early diagnosis of breast cancer. ${ }^{8}$

Hormone therapy is known to increase the density of the breast parenchyma. However, this does not occur in the majority of women, ${ }^{18,20,22,28}$ and this stimulus is also known to vary according to the type of hormone therapy used. In view of these factors, the groups were matched for duration of HT use and for the type of hormone used (CEE + MPA), Nonetheless, matching for exclusively cyclic or continuous use was not possible, since younger women with POF often want to menstruate, whereas postmenopausal women prefer continuous regimes in order to avoid bleeding.

Although age has been shown to have an inverse correlation with breast density, ${ }^{29}$ this association was not found in the study group or in the control group of postmenopausal women. Although the women in the study group were younger, their breast density was similar to that of the older postmenopausal women.

No significant difference in breast density was found between the two groups in this study, despite the fact that the groups had very different characteristics. This latter point has encouraged us to proceed with designing a new, prospective study involving data correlation that would enable greater precision of control over the variables that affect each woman participating in the study.

Finally, based on the results from this pilot study, and considering the likelihood of type I error as 0.05 (alpha $=0.05$ ) and a test power (type II error) of $80 \%(1$ - beta $=0.80)$, we recommend that for further studies, a sample size of at least 92 patients in each group should be used.

It is important to take into account the fact that the diagnosis of POF is established at a rate of about one case for every 1,000 women. 
This ratio may make it hard to achieve bigger samples than the present one.

Although the authors are aware of the limitations of the present sample size, this was a pilot study. Hence, the findings described here are important because this is the first paper reporting on the effects of estrogen-progestin HT on the breast density of women with POF compared to that of postmenopausal women using the same type of HT for similar periods of time.

The patients enrolled in this study are being followed up for prospective evaluation proposals.

Finally, it should be stressed that the question of hormone treatment remains open. New studies would be necessary, with bigger sample sizes if possible, in order to answer women's concerns and thus promote better compliance with treatment.

\section{CONCLUSIONS}

There was no difference in breast density between the women with POF and the postmenopausal women who had used the same HT during similar periods.

\section{REFERENCES}

1. Rossouw JE, Anderson GL, Prentice RL, et al. Risks and benefits of estrogen plus progestin in healthy postmenopausal women: principal results From the Women's Health Initiative randomized controlled trial. JAMA. 2002;288(3):321-33

2. Beral V; Million Women Study Collaborators. Breast cancer and hormone-replacement the rapy in the Million Women Study. Lancet. 2003;362(9382):419-27.

3. Conner P, Svane G, Azavedo E, et al. Mammographic breast density, hormones, and growth factors during continuous combined hormone therapy. Fertil Steril. 2004;81(6):1617-23.

4. Chen FP, Cheung YC, Teng LF, Soong YK. The relationship between mammographic density and duration of hormone therapy: effects of estrogen and estrogen-progestin. Hum Reprod. 2005;20(6):1741-5

5. Harvey J, Scheurer C, Kawakami FT, et al. Hormone replacement therapy and breast density changes. Climacteric. 2005;8(2):185-92.

6. Junkermann $\mathrm{H}$, von Holst T, Lang E, Rakov V. Influence of different HRT regimens on mammographic density. Maturitas. 2005;50(2):105-10.

7. Christodoulakos GE, Lambrinoudaki IV, Vourtsi AD, et al. The effect of low dose hormone therapy on mammographic breast density. Maturitas. 2006;54(1):78-85.

8. Kavanagh AM, Mitchell H, Giles GG. Hormone replacement therapy and accuracy of mammographic screening. Lancet. 2000;355(9200):270-4.

9. Banks E. Hormone replacement therapy and the sensitivity and specificity of breast cancer screening: a review. J Med Screen. 2001;8(1):29-34.

10. Warren R. Hormones and mammographic breast density. Maturitas. 2004;49(1):67-78.

11. Armitage M, Nooney J, Evans S. Recent concerns surrounding HRT. Clin Endocrinol (0xf). 2003;59(2):145-55.

12. Mann RD. Hormone replacement therapy and breast cancer risk: studies of the last fifteen years. In: Mann RD, editor. Hormone replacement therapy and breast cancer risk. New Jersey: Parthenon Publishing Group; 1992. p. 1-8.

13. Boyd NF, Byng JW, Jong RA, et al. Quantitative classification of mammographic densities and breast cancer risk: results from the Canadian National Breast Screening Study. J Natl Cancer Inst. 1995;87(9):670-5.

14. Byrne C, Schairer C, Wolfe J, et al. Mammographic features and breast cancer risk: effects with time, age, and menopause status. J Natl Cancer Inst. 1995;87(21):1622-9.

15. Maskarinec G, Meng L. A case-control study of mammographic densities in Hawaii. Breast Cancer Res Treat. 2000;63(2):153-61.

16. Vachon CM, Kuni CC, Anderson K, Anderson VE, Sellers TA. Association of mammographically defined percent breast density with epidemiologic risk factors for breast cancer (United States). Cancer Causes Control. 2000;11(7):653-62.

17. Noh JJ, Maskarinec G, Pagano I, Cheung LW, Stanczyk FZ. Mammographic densities and circulating hormones: a cross-sectional study in premenopausal women. Breast. 2006;15(1):20-8.
18. Laya MB, Gallagher JC, Schreiman JS, et al. Effect of postmenopausal hormonal replacement therapy on mammographic density and parenchymal pattern. Radiology. 1995;196(2):433-7

19. Breast cancer and hormone replacement therapy: collaborative reanalysis of data from 51 epidemiological studies of 52,705 women with breast cancer and 108,411 women without breast cancer. Collaborative Group on Hormonal Factors in Breast Cancer. Lancet. 1997:350(9084):1047-59.

20. Marugg RC, van der Mooren MJ, Hendriks JH, Rolland R, Ruijs SH. Mammographic changes in postmenopausal women on hormonal replacement therapy. Eur Radiol. 1997;7(5):749-55.

21. Koukoulis GN. Hormone replacement therapy and breast cancer risk. Ann N Y Acad Sci. 2000;900:422-8.

22. Lundström E, Wilczek B, von Palffy Z, Söderqvist G, von Schoultz B. Mammographic breast density during hormone replacement therapy: effects of continuous combination, unopposed transdermal and low-potency estrogen regimens. Climacteric. 2001;4(1):42-8.

23. Greendale GA, Palla SL, Ursin G, et al. The association of endogenous sex steroids and sex steroid binding proteins with mammographic density: results from the Postmenopausal Estrogen/Progestin Interventions Mammographic Density Study. Am J Epidemiol. 2005;162(9):826-34.

24. de Moraes-Ruehsen M, Jones GS. Premature ovarian failure. Fertil Steril. 1967;18(4):440 61.

25. Cymberknoh M. Mamografia digital. In: Dias EN, Caleffi M, Silva HMS, Figueira-Filho ASS, eds. Mastologia atual. Rio de Janeiro: Revinter; 1994. p. 75-8.

26. Wolfe JN. Breast patterns as an index of risk for developing breast cancer. AJR Am J Roentgenol. 1976;126(6):1130-7.

27. Snedecor WG, Cochram WG. The comparison of two samples. In: Snedecor WG, Cochram WG, editors. Statistical methods. $8^{\text {th }}$ ed Ames: Iowa State University Press; 1989. p. 83 102

28. Persson I,Thurfjell E, Holmberg L. Effect of estrogen and estrogen-progestin replacement regimens on mammographic breast parenchymal density. J Clin Oncol. 1997;15(10):3201-7.

29. Harvey JA, Bovbjerg VE. Quantitative assessment of mammographic breast density: relationship with breast cancer risk. Radiology. 2004;230(1):29-41

Sources of funding: None

Conflict of interest: None

Date of first submission: October 28, 2009

Last received: June 17, 2010

Accepted: June 23, 2010

Address for correspondence:

Cristina Laguna Benetti-Pinto

Rua João Simões da Fonseca, 598

Loteamento Residencial Barão do Café

Campinas (SP) - Brasil

CEP 13085-050

Tel. (19) 3521-9306

Fax. (19) 3521-9306

E-mail: crislag@sigmanet.com.br 